\title{
The Scope Taxation in Influencing Entrepreneurship: Historical Overview of Tax Policies
}

\author{
Anthony Ray Martin (Corresponding author) \\ University of the Incarnate Word, USA \\ E-mail: amart667@fiu.edu
}

Received: December 4, 2018 Accepted: December 20, 2018 Published: January 28, 2019

doi:10.5296/ber.v9i1.13996

URL: https://doi.org/10.5296/ber.v9i1.13996

\begin{abstract}
Policymakers constantly face the challenge of aligning micro- and macroeconomic policies with the existing needs of the social, political and economic facets of their areas of jurisdiction. Given the pivotal role played by taxation in any economy, it is not surprising that many countries often turn to tax breaks as a method of easing pressure on existing enterprises with the hope of sparking investment. One common explanation for issuing such breaks is that taxation affects microeconomic decisions undertaken by organizations in terms of investments, innovation and job creation and policies of the existing tax regime directly affect opportunities for enterprises that may seek to venture beyond the boundaries of a taxation authority's area of jurisdiction. However, empirically, the world of entrepreneurship is difficult to analyze. This is especially true when identifying the relationship between taxpromoted economic activities of entrepreneurs and the overall behavior of different businesses. This paper reviews the scope of taxation within the US's economic policy through a historical analysis of the manner in which the Bush, Obama and Trump administrations utilized policy tools to shape the course of the country's micro- and macro-economic conditions.
\end{abstract}

Keywords: Tax cuts, Economic growth, Corporate tax

\section{Effects of Tax Breaks on Entrepreneurship and Overall Economic Growth}

Access to finance remains one of the greatest challenges for businesses, especially among small and medium-sized enterprises (Rupeika-Apoga, 2014). However, SMEs remain key players in economic growth, playing a major role in employment creation, influencing the balance of trade, and impacting innovation. Thus, SMEs are at the core of America's competitiveness (Mills \& McCarthy, 2014). Tax breaks play a major role in incentivizing small and medium-sized business activity within economies. A flourishing SME environment is key to the attainment of economic growth particularly by fostering employment growth and 
spurring economic progress (Glaeser, Kerr \& Ponzetto, 2010). Therefore, different jurisdictions seek to outdo each other by implementing favorable terms in to attract small business players particularly in industries such as nanotechnology, biotechnology, and advanced manufacturing (Chatterji, Glaeser \& Kerr, 2014).

Tax policies exist with the objective of complementing the growth and development strategy of a country over time. As Addison, Nino-Zarazua and Pirttila (2018) contend, fiscal policy remains a pivotal part of influencing the path of economic growth adopted by an economy especially in situations where the need to achieve inclusive growth exists. Economic growth and innovation are inseparable twins in contemporary economics (Torun \& Cicekci, 2007). In that regard, the role of small and medium-sized enterprises in creating a large share of breakthrough inventions remains a critical part of modern economies that may seek to yield a competitive advantage through improved research and development (R\&D) and enhanced market outreach aggressiveness (Haufler, Norback \& Persson, 2014). Indeed, entrepreneurs commonly cite tax regulations and tax rates as the key problems facing the establishment of commercial entities (Baliamoune-Lutz \& Garello, 2014). Therefore, the task of compiling an appropriate tax regime requires policy makers to examine different dimensions to avoid orchestrating a financial crisis. Financial and economic crises tend to cause significant increments in unemployment levels, and the presence of a high tax burden only serves to make things worse.

The role of the state in fostering economic development keeps evolving and recently has moved from overreliance on industrial recruitment to emphasis on entrepreneurial strategies. There are various reasons why governments implement tax reform measures, some of which include the need to provide economic stimulus and the importance of addressing inequity. The outcome of any tax policy is to eventually raise the amount of revenue collected from such interventions. Such revenue can later be used to fund government operations and development agendas without having to resort to government borrowing.

According to Barret, Duffy, and McQuinn (2015), tax breaks are fiscal measures that are geared toward stimulating local and foreign investment capital, especially in response to the need to activate growth in specific sectors of the economy. Indeed, to a large extent, tax breaks provide favorable conditions which encourage international businesses to move their headquarters to the country offering these benefits. This, in turn, leads to generation of jobs and production of goods at lower costs of production. In general, tax incentives end up promoting investment, employment creation, and foreign direct investment. Tax cuts influence entrepreneurial behavior through both income and substitution effects. Overall, the positive effects of such rate cuts arise in the form of growth in savings and investments. In addition, rate cuts play a key role in helping to eliminate economic distortions alongside facilitating an efficiency-improving shift, particularly in the composition of a country's economic activity.

From another perspective, tax reforms that focus on spreading tax cuts involve the reduction of tax rates, which in turn broaden the tax base (Gale \& Samwick, 2016). A broader base then expands the overall size of an economy through the reduction of the tax burden and the 
overall increment in profitability of resource-deprived sectors and industries. This also improves the competitiveness of local firms, further enhancing economic growth and expanding potential revenue collections by tax regimes. Tax cuts also help diminish the effects of economic cycles, especially when a country seeks to recover from a recession period. For instance, following the 2008 economic recession, the 2008-10 Tax Stimulus Acts provided for larger temporary tax cuts with the goal of helping the country recover from the Great Recession. To understand the impact of tax breaks, it is imperative to compare how different regimes have implemented them in the recent past.

\section{The Bush Administration's Tax Reforms}

The Bush administration implemented a series of tax breaks between the years 2001 and 2003 . The Economic Growth and Tax Relief Reconciliation Act of 2001 (EGTRRA) implemented the 2001 tax breaks, and the Growth Tax Relief Reconciliation Act of 2003 (JGTRRA) implemented the 2003 tax breaks. EGTRRA was a sweeping piece of tax legislation which brought about major changes to the internal revenue code and particularly affected income tax rates and gift tax exclusions. The overall effect of EGTRRA was a significant decline in the estate tax. The general idea was that a high estate tax discourages entrepreneurs from investing their resources, particularly in their entrepreneurial activities.

Opponents of the estate tax refer to it as a "death tax." Some scholars, like De Nardi and Yang (2016), argue that the estate tax is immoral and counter-productive, which means it also affects small businesses and an economy's ability to keep jobs. Thus, EGTRRA aimed to overcome such challenges to boost entrepreneurship. As for JGTRRA, the Bush administration sought to jump-start a slackening U.S. economy by reducing the amount of taxes investors paid on capital gains and dividends. Ostensibly, policymakers intended this development to encourage public companies to pay dividends in cash to their shareholders, thereby discouraging such shareholders from holding onto their shares or reinvesting them into expanded operations. JGTRRA focused on cutting individual rates, the estate tax, dividends, and capital gains.

The overall effect of both EGTRRA and JGTRRA was to initially lead to a significant drop in the cost of operation, which further drove up entrepreneurial spending power. This, in turn, led to massive job growth. As Marr and Brunet (2010) note, these tax reforms led to significant job income growth, especially among those earning above $\$ 250,000$ per year. Following this came claims that the Bush tax cuts created eight million jobs over a period of 10 years (Ungar, 2012). On the other hand, Thoma (2010) demonstrates that, in fact, the Bush administration tax cuts led to a reduction in median household income. As Mitchell and Castillo (2012) demonstrate, the Bush tax cuts had several issues, especially when considered from a market-oriented perspective. This was because these tax cuts took place without any effort to reduce mass spending, which eventually led to detrimental effects on the economy at large.

The situation following the implementation of both EGTRRA and JGTRRA worsened with the 2008 economic recession, which led to a massive decline in economic growth and a record-high rise in the unemployment rate to $10.1 \%$ by October 2009 (Hungerford, 2010a). 
As such, even though the initial intention of rolling out the Bush tax breaks was to speed up economic growth, the cumulative effect of such measures slowed down the economy. This slowdown occurred because the tax cuts enhanced spending power without controlling spending behavior, something that led to detrimental effects in the economy and eventually contributed to the Great Recession.

\section{The Obama Administration's Tax Reforms}

The Obama administration implemented further tax cuts through the 2010 Obama Tax Cuts law, which extended the Bush tax cuts through 2012. The Obama tax law decreased payroll taxes by $2 \%$, effectively adding $\$ 120$ million to employees' disposable income. In addition, the Obama administration applied $\$ 55$ billion to industry-specific tax cuts, including agriculture and energy industries, two sectors which continued to receive tax credits at a cost of $\$ 6$ billion in 2011. Further, the Obama tax law applied a 35\% tax rate on estates with an exemption of $\$ 5$ million (Eggen, 2010). The Obama tax measures favored American middle-income earners, giving rise to a concept known as "middle-class economics." The overall objective of reviving the economy by empowering the middle class stemmed from the fact that middle-income earners form a major part of the U.S. active population; therefore, by empowering them, the Obama administration sought to create a trickledown effect that would spur the entire economy. Pressman (2015) argues that the middle-class segment of our society plays a pivotal role in economic growth; therefore, recognizing the unique role people in this class play by offering them a tax reprieve would have a significant effect on economic growth.

Implementing tax reforms that target a particular income segment is one of the policy decisions that promote income distribution and, hence, reduce inequality. In general, a constant rise in the gross domestic product per capita of the middle class positively contributes to economic growth. This growth results from a significant increase in levels of worker productivity and spending power, which ensures an economy can support many upcoming innovations (Brueckner, Dabla-Norris, Gradstein \& Lederman, 2018). For instance, Kharas and Gertz (2010) associate the fast growth of the South Korean and Brazilian economies to the fast-growing middle-income segment of the economy. Banerjee and Duflo (2008) identify three arguments supporting the fact that growth in middle-class populations benefits economies. The first argument is that this segment of the society is primarily made up of entrepreneurs who foster innovation and create new companies that, in turn, favor job creation. The second argument underscores the fact that the middle class tends to have values that encourage general practices of accumulation of human capital. The third argument points to the fact that high consumption power characterizes a middle-class dominated economy, which then leads to expansion of markets and widespread diversification. This creates room for further exploitation of the existing economies of scale as far as production is concerned.

At the core of Obama's tax reforms was the desire to favor the majority by imposing high tax rates on individuals who made millions of dollars a year. This desire follows the argument that Wall Street firms were entirely responsible for the U.S. economic recession, which left average Americans at a disadvantage (Miroff, Seidelman, Swanstrom \& De Luca, 2014). The 
Obama administration took over the government at a time when the nation was right in the middle of a recession. Therefore, the administration's 2010 tax reforms aimed to provide even ground for the economy to grow, and this involved targeting middle-income earners who formed a pivotal part of the recovery agenda. The overall impact of this approach was that the economy grew, although at a sluggish pace. While Obama's moderate tax reforms yielded mixed effects for the overall economy, they mainly aided in the mitigation of unemployment rates, which had risen to a high of $9.8 \%$ in December 2010. His tax stimulus reforms created 3.3 million jobs within the first few years of his administration's first term (Jacobson, 2011). However, the Obama tax reforms failed to support the manufacturing sector. Atkinson, Stewart, Andes, and Ezell (2012) report significant job cuts in the post-recession period of the Obama administration. To this end, the mixed results of the Obama tax breaks, though largely effective, came under the influence of post-recession, internal resistance from high-income earners, and the impact of Hurricane Sandy.

\section{The Trump Administration's Tax Reforms}

The Trump Administration took over power at a time when the US was experiencing a myriad of challenges including high unemployment rates and a dipping corporate activity as companies sought to move their operations from the country owing to high corporate tax. As Ljungqvist and Smolyansky (2014) argued, corporate tax rates affect demand for labor and influence operations cost. Another challenge this administration faced was the need to restore the country's economic growth which sluggishly recovered from the 2008 recession (Blinder $\&$ Watson, 2013). In addition, the new government needed to restore the country's global competitiveness under the "Make America Great Again" mantra.

In line with the precedent set by the preceding administrations, the Trump government instituted a raft of reforms aimed to impact personal and corporate tax with the objective of stimulating economic growth. The Tax Cuts and Job Act, which was assented to on 22 December 2017 came into full effect in 2018. A closer look at it reveals a two-prong approach - that is (1) focus on lowering corporate tax and removal of penalties on repatriation of foreign profits (2) focus on reducing personal tax on middle and low-income earners.

The 2017 tax law majorly includes elements of reducing tax rates for individuals as well as corporate institutions. For instance, it limits the State and Local Income Taxes (SALT) alongside property taxes with the objective of easing the tax burden on individuals. On the macroeconomic front, this Act aims to stimulate economic growth by building on investor confidence and encouraging job creation. However, the Congressional Budget Office (CBO) notes, the Act increases the likelihood of growing the national debt over the next ten years by close to $\$ 1.455$ trillion (Sutor, 2018). On a positive note though, Bryan (2017) observed that the US Gross Domestic Product (GDP) would grow by $0.7 \%$. This is in line with the Joint Committee on Taxation report which further estimated a job creation rate of $0.6 \%$ and an overall rise in the level of personal consumption levels of $0.6 \%$ between 2018 and 2027 (Joint Committee on Taxation, 2017). The forecast growth rates remain significantly lower than the new administration initially estimated at 3 to $5 \%$ growth per year indicating that this Act may struggle to "pay for itself" in the long-run (Bryan, 2017). As far as corporate taxation is 
concerned the newly enacted law lowers corporate tax to $21 \%$ down from $35 \%$ implemented under the Obama administration. It is worth noting that a 35\% tax was the highest in the industrial world (Hungerford, 2012b). The argument under the Trump administration is that such a costly tax made US companies less competitive on a global arena in addition to discouraging new companies from setting up shop in the US. In theory, high taxation rates yield less disposable income for corporate organizations and, therefore, reduce their profits and negatively affect the incentive to create job positions.

In seeking to encourage foreign-based companies to re-invest their wealth within the country, the new tax law removed the penalty on repatriation of foreign profits. Under the Obama administration, this penalty stood at 35\%. Its removal under this new tax regime, therefore, seeks to create an enabling environment in order for companies to bring back an estimated $\$ 2.5$ trillion of their overseas earnings (Cox, 2016). However, Laplante and Nesbitt (2017) argue that the underlying figure of $\$ 2.5$ trillion comprises permanently reinvested earnings and not necessarily foreign cash and should, therefore, not be mistaken for untaxed foreign earnings that the government can opt for as a readily available source of tax revenue in a bid to stimulate economic activity within the country.

As far as agriculture is concerned, the new tax code provides that pass-through entities, such as family farms, and sole proprietorships will be taxed under individual tax bands minus a deduction of up to 20 percent (Erb, 2018). As Edwards (2018) contends, it is the role of government to protect farmers against market price fluctuations, unreliable yields and revenues. Therefore, the federal government needs to cushion farmers in order to support this crucial economic sector. The Trump law seems right on course to achieving that feat.

Regarding personal tax, the new tax law eases the burden on single parents and 4-person families. Single parents earning more than $\$ 35,000$ paid $\$ 158$ in the previous tax regime. However, under the new law, such individuals receive a tax refund of \$366. Likewise, families made up of 4 members pay nil tax under this new law for income under $\$ 61,000$ up from the $\$ 48,000$ limit set under the Obama administration. To this end, this new law seeks to cushion low income earners and provide the burgeoning middle-class with increased disposable income with the objective of driving consumption. As Banerjee and Duflo (2008) note, middle income consumption habits play a major role in fueling economic growth and favoring the development of laws that are of great benefit to the public.

Under the Tax Cuts and Job Act are seven different tax bands as was the case under the Obama administration (Mercado, 2018). However, the rates have been tweaked. The previous law contained $10 \%, 15 \%, 25 \%, 28 \%, 33 \%, 35 \%$ and $39.6 \%$ bands. On the other hand, the new tax code breaks down the rates as follows.

- 10 percent for 0 to $\$ 9,525$

- 12 percent for $\$ 9,525$ to $\$ 38,700$

- 22 percent for $\$ 38,700$ to $\$ 82,500$

- 24 percent for $\$ 82,500$ to $\$ 157,500$ 
- 32 percent for $\$ 157,500$ to $\$ 200,000$

- 35 percent for $\$ 200,000$ to $\$ 500,000$

- 37 percent for $\$ 500,000$ upwards

For married couples who file jointly, the first 10 percent band remains unchanged for the first $\$ 19,050$ earned. However, there's a reduction from $15 \%$ to $12 \%$ for the $\$ 19,050$ to $\$ 77,400$ tax band. Likewise, the tax rate for the $\$ 77,400$ to $\$ 165,000$ income currently stands at $22 \%$ down from $25 \%$ for the $\$ 77,400$ to 156,150 brackets respectively. Yet another unique aspect of this new law is the removal of personal exemptions. Previously, one could claim a $\$ 4,050$ personal exemption or do the same for each of their dependents in order to lower their taxable income. However, this facility no longer exists. As Horowitz (2017) argues, for some households, the end of personal exemption comes with the potential to negate the tax relief individuals may gain from other aspects of this reform package. Trump's tax law further exempts many more people from estate tax. Under the previous law, the amount of money exempt from this tax stood at $\$ 5.49$ million and $\$ 10.98$ million for couples (Huang \& Debot, 2017). This, under the Tax Cuts and Job Act has been doubled to $\$ 10.98$ million for individuals and \$21.96 million for married couples.

\section{Overall Effects of Tax Breaks on Entrepreneurship}

Normally, different forms of taxation leave entrepreneurs with less disposable capital. Therefore, the higher the implemented tax rates, the more capital entrepreneurs lose to government coffers. Therefore, in theory, high taxes mean entrepreneurs have less money to invest in their businesses, and this eventually leads to a slowdown in job creation. By introducing tax breaks, the main objective remains to provide enterprises, both large and small, with favorable terms to bolster profitability. This is especially desirable when policymakers deem that high tax rates will eat into company profits. Carroll and Prante (2012) concur with Harju and Kosonen (2012) that high tax rates eventually lead to lower output and consequently higher unemployment rates. This can cause contraction of a country's GDP, which will eventually lead to a significant decline of global competitiveness along with other internal and external economic shocks.

High tax rates are also associated with lower investment levels. This happens due to the lack of investment incentives, especially because business growth eventually leads to higher tax levels. This also reduces incentives for innovation since any new business ideas on the market would face heavy tax burdens. The average tax rates play a significant role for investors who seek to make the best investment choices (Simron, Ganser, McLiesh, Ramalho, $\&$ Schleifer, 2010). By and large, this can affect factors such as foreign direct investment because an expensive tax regime would translate into less profit; hence, fewer entrepreneurs would be interested in moving their businesses to a country with such regulations.

Besides encouraging entrepreneurship and reducing unemployment, tax breaks also play a role in broadening a country's tax base. This can be achieved because more businesses are likely to emerge under a low-tax regime. Further, innovation levels are likely to rise whenever an enabling environment is provided. In a nutshell, this favors the establishment of 
new industries, which increases income streams upon which a government can impose taxes. A broadened tax base raises the average effective marginal tax rates on investment, savings, and labor supply, and this has two effects. First, it reduces the average substitution effect because a low-tax regime increases the incentive to work, save, and invest. Second, base broadening expands the economy and effectively reduces the allocation of key resources to only a few industries, thereby encouraging the government to cease pressuring the traditional sector and move into new areas likely to yield even higher pre-tax returns (Gale \& Samwick, 2014). As Hungerford (2012b) contends, the additional revenues collected from a wider tax base would be utilized to reduce budget deficits and favor tax rate reductions.

In general, those who argue in favor of tax reductions, such as Macek (2014), argue that cheaper taxes would spur economic growth, boost productivity, and enhance savings as well as investments. On the other hand, those who argue in favor of higher tax rates, like Desai, Foley, and Hines (2007) indicate, more taxation promotes economic independence, which further helps to reduce debt and income inequality by altering the way the economic pie is distributed. Indeed, one of the short-term and medium-term effects of lower taxation is revenue reduction, which increases the budget deficit and forces the government to incur more debt in order to run its basic functions. Higher income tax rates tend to make the entire tax system more progressive. As Hungerford (2012b) demonstrates, although lower taxes tend to increase entrepreneurship and capital investment, governments do not achieve such growth through national savings. Therefore, such a country would often have to rely on foreign borrowing to sustain a stable flow of finances. From an economic perspective, the overall impact of tax breaks remains ambiguous. Lower taxes are associated with larger after-tax returns on savings, which means that individuals can achieve higher target levels of wealth despite saving less. As such, this form of wealth creation would be the result of an income effect which, as Hungerford (2012b) demonstrates, is associated with lower tax collections, leading to less national savings (given that public and private savings are components of national savings). On the contrary, higher taxes would result in reduced after-tax income, which is generally associated with deferring present consumption to consume more in the future. This is called the substitution effect and, as Hungerford (2012b) argues, leads to more savings. Roach (2010) demonstrates that historically, although the public perception has generally been in favor of lower tax rates, high tax rates have played a role in helping the U.S. maintain its sovereignty and independence, especially during the War of 1812 when the government temporarily raised federal taxes to pay down ensuing debts and finance the war.

Assuming imperfect credit markets, Guo and Luo (2017) noted that since companies need to pay sunk costs before exporting their products, even when profitable, they find it difficult to access credit from foreign markets. However, a country like the US with a strong contractual enforcement regime, companies can export to more destinations. Contrariwise, a weaker contractual enforcement regime denies companies the requisite credit that would have otherwise allowed for export to more destinations (Guo \& Luo, 2017). However, for companies with either very high or very low productivity, the foregoing does not happen. President Trump is particular on markets. His "American First" mantra has been about American companies 
investing locally for the benefit of America's economy. Since the US has a strong contractual enforcement regime, American companies can produce more and export more, and to more countries. With such a regime coupled with the Tax Cuts and Jobs Act, which sought to reduce corporate tax from 35 per cent to 21 per cent, more companies will invest in the country without becoming overly worrisome of paying sunk costs.

\section{Conclusion}

While one may argue that tax breaks favor entrepreneurship and enhance overall economic growth, it is always important to note that lower taxes can significantly impact revenue collection and slow down an economy. Besides that, whenever policymakers issue a tax break on a certain economic group, they are often forced to put more pressure on another sector of the economy to stabilize revenue collection in the short-run. In the recent past, different American governments have opted for a progressive tax regime, especially one that favors the middle class at the expense of the rich. While such an approach boosts innovation, entrepreneurship, and promotes job creation, it negatively affects the rich who eventually opt to incorporate their companies abroad and place their savings offshore. Therefore, this yields a counter-productive effect, which necessitates a thorough re-examination of modern-day and future policymaking.

The study was not exhaustive enough due to limitations of scope, time, and other factors. Further research is therefore required. There are different directions that scholars can take in future research. One of them is provide quantitative evidence to support the paper's main arguments. This would allow for inclusion and discussion of more different aspects of tax impact in influencing entrepreneurship. Proving a quantitative comparison would definitely help understand the correlation between taxation and entrepreneurial activities. Future empirical studies could also could illuminate how different taxes interact and the implications of tax policies on different entrepreneurial activities.

\section{References}

Addison, T., Niño-Zarazúa, M., \& Pirttilä, J. (2018). Fiscal policy, state building and economic development. Journal of International Development, 30(2), 161-172.

https://doi.org/10.1002/jid.3355

Atkinson, R. D., Stewart, L. A., Andes, S., \& Ezell, S. (2012, March). Worse than the Great Depression: What experts are missing about American manufacturing decline. Information Technology and Innovation Foundation. [Online] Available:

http://www2.itif.org/2012-american-manufacturing-decline.pdf?_ga=2.214689105.79279827 7.1518540706-1770238221.1518540706 (Ocober 3, 2019)

Baliamoune-Lutz, M., \& Garello, P. (2014). Tax structure and entrepreneurship. Small Business Economics, 42(1), 165-190. https://doi.org/10.1007/s11187-013-9469-9

Banerjee, A., \& Duflo, E. (2008). What is middle class about the middle classes around the world?. Journal of Economic Perspectives, 22(2), 3-28. https://doi.org/10.1257/jep.22.2.3

Barrett, A., Duffy, D., \& McQuinn, K. (2015, September). Tax breaks and the residential 
property market. Economic and Social Research Institute. [Online] Available:

http://www.budget.gov.ie/Budgets/2016/Documents/ESRI_Report_on_tax_breaks_and\%20_r esidential_property_market_pub.pdf (December 11, 2018)

Blinder, A. S., \& Watson, M. W. (2013). Presidents and the economy: A forensic investigation. Mimeo.

Brueckner, M., Dabla-Norris, E., Gradstein, M., \& Lederman, D. (June 01, 2018). The rise of the middle class and economic growth in ASEAN. Journal of Asian Economics, 56, 48-58. https://doi.org/10.1016/j.asieco.2017.12.008

Bryan, B. (2017, December 1). A brutal new analysis shows the GOP tax bill would do little for US economic growth. Business Insider. [Online] Available:

https://www.businessinsider.com.au/trump-gop-tax-reform-bill-analysis-economic-growth-20 17-12 (July 23, 2018)

Carroll, R., \& Prante, G. (2012). Long-run macroeconomic impact of increasing tax rates on high-income taxpayers in 2013. Ernest \& Young. [[Online] Available:

https://waysandmeans.house.gov/UploadedFiles/EY_Study_Long-run_macroeconomic_impa ct_of_increasing_tax_rates_on_high_income_taxpayers_in_2013_2012_07_16_FINAL.pdf (August 8, 2018)

Chatterji, A., Glaeser, E., \& Kerr, W. (2014). Clusters of entrepreneurship and innovation. Innovation Policy and the Economy, 14(1), 129-166. https://doi.org/10.1086/674023

Cox, J. (2016, September 20). US Companies are hoarding \$2.5 trillion in cash overseas. CNBC. [Online] Available:

https://www.cnbc.com/2016/09/20/us-companies-are-hoarding-2-and-a-half-trillion-dollars-in -cash-overseas.html (June 28, 2018)

De Nardi, M., \& Yang, F. (2016). Wealth inequality, family background, and estate taxation. Journal of Monetary Economics, 77, 130-145. https://doi.org/10.1016/j.jmoneco.2015.10.005

Desai, M. A., Foley, C. F., \& Hines, J. R. (2007, December). Labor and capital shares of the corporate tax burden: International evidence. In Conference on who pays the corporate tax in an open economy. [Online] Available: http://www.people.hbs.edu/ffoley/labcapshr.pdf (September 20, 2018)

Edwards, C. (2018). Agricultural subsidies. Downsizing Government Project. [Online] Available: https://www.downsizinggovernment.org/agriculture/subsidies (September 19, 2018)

Eggen, D. (2010, December). Tax-cut legislation includes $\$ 55$ billion in benefits for a host of industries. Washington Post. [Online] Available:

http://www.washingtonpost.com/wp-dyn/content/article/2010/12/15/AR2010121504071.html ?nav=emailpage (July 29, 2018)

Erb, P., K. (2018). What the new tax deduction for pass-through businesses looks like in chart form. Forbes. [Online] Available: 
https://www.forbes.com/sites/kellyphillipserb/2018/01/18/what-the-tax-deduction-for-pass-th rough-businesses-looks-like-in-chart-form/\#4a8ebef74a0f (December 11, 2018)

Gale, W. G., \& Samwick, A. A. (2016, February). Effects of income tax changes on economic growth. [Online] Available:

https://www.brookings.edu/wp-content/uploads/2016/07/09_Effects_Income_Tax_Changes_ Economic_Growth_Gale_Samwick_.pdf (November 13, 2018)

Glaeser, E. L., Kerr, W. R., \& Ponzetto, G. A. (2010). Clusters of entrepreneurship. Journal of Urban Economics, 67(1), 150-168. https://doi.org/10.1016/j.jue.2009.09.008

Guo, Z. Y., \& Luo, Y. (2017). Credit constraint exports in countries with different degrees of contract enforcement. Business and Economic Research, 7(1), 227-241.

https://doi.org/10.5296/ber.v7i1.10923

Harju, J., \& Kosonen, T. (2012). The impact of tax incentives on the economic activity of entrepreneurs (NBER Working Paper No. 18442). National Bureau of Economic Research. [Online] Available: http://www.nber.org/papers/w18442.pdf (January 2, 2019)

Haufler, A., Norbäck, P. J., \& Persson, L. (2014). Entrepreneurial innovations and taxation. Journal of Public Economics, 113, 13-31. https://doi.org/10.1016/j.jpubeco.2014.03.002

Horowitz, J. (2017, December 20). 34 things you need to know abou the incoming tax law. CNN Money. [Online] Available:

http://money.cnn.com/2017/12/20/news/economy/republican-tax-reform-everything-you-need -to-know/index.html (March 5, 2018)

Huang, C. C., \& DeBot, B. (2015). Ten facts you should know about the federal estate tax. Center on Budget and Policy Priorities. [Online] Available:

http://www.law.uh.edu/faculty/wstreng/EstatePlanning2015/Ten_Facts_re_Estate_Tax_2015. pdf (January 22, 2018)

Hungerford, T. L. (2010a). Bush tax cuts and the economy. DIANE Publishing. [Online] Available: https://fas.org/sgp/crs/misc/R41393.pdf (January 2, 2019)

Hungerford, T. L. (2012b). Taxes and the economy: An economic analysis of the top tax rates since 1945 (Updated). Online] Available: https://fas.org/sgp/crs/misc/R42729.pdf (March 9, 2018)

Jacobson, G. C. (2011). Legislative success and political failure: The public's reaction to Barack Obama's early Presidency. Presidential Studies Quarterly, 41(2), 220-243. https://doi.org/10.1111/j.1741-5705.2011.03852.x

Joint Committee on Taxation (2017, November 16). A distribution of returns by the committee on finance on November 16, 2017. Wall Street Journal. [Online] Available: https://www.wsj.com/public/resources/documents/JCT-distribution-of-tax-returns-D-17-54.pd $\mathrm{f}$

Kharas, H., \& Gertz, G. (2010). The new global middle class: A cross-over from West to East. 
Wolfensohn Center for Development at Brookings. [Online] Available: https://www.brookings.edu/wp-content/uploads/2016/06/03_china_middle_class_kharas.pdf (August 12, 2018)

Laplante, S. K., \& Nesbitt, W. L. (2017). The relation among trapped cash, permanently reinvested earnings, and foreign cash. Journal of Corporate Finance, 44, 126-148. https://doi.org/10.1016/j.jcorpfin.2017.03.005

Ljungqvist, A., \& Smolyansky, M. (2014). To cut or not to cut? On the impact of corporate taxes on employment and income (No. w20753). National Bureau of Economic Research. http://dx.doi.org/10.17016/FEDS.2016.006.

Macek, R. (2014). The impact of taxation on economic growth: Case study of OECD countries. Review of Economic Perspectives, 14(4), 309.

https://doi.org/10.1515/revecp-2015-0002

Marr, C., \& Brunet, G. (2010, August). Extension of high-income tax cuts would benefit few small businesses; jobs tax credit would be better. Center on Budget and Policy Priorities. [Online] Available: https://www.cbpp.org/sites/default/files/atoms/files/8-3-10tax.pdf (April 5, 2018)

Mercado D. (2018, Jan 1). New year, new tax brackets. Here's where you stand. CNBC. Retrieved from:

https://www.cnbc.com/2017/12/29/heres-where-you-stand-in-the-new-2018-tax-brackets.html (April 6, 2018)

Mills, K., \& McCarthy, B. (2014, July). The state of small business lending: Credit access during the recovery and how technology may change the game (Working Paper 15-004). [Online] Available:

https://www.hbs.edu/faculty/Publication\%20Files/15-004_09b1bf8b-eb2a-4e63-9c4e-0374f7 70856f.pdf (October 22, 2018)

Miroff, B., Seidelman, R., Swanstrom, T., \& De Luca, T. (2014). The democratic debate: American politics in an age of change. Nelson Education.

Mitchell, M. D., \& Castillo, A. M. (2012, November). What went wrong with the Bush tax cuts. Mercatus Research. [Online] Available:

https://papers.ssrn.com/sol3/papers.cfm?abstract_id=2196167 (January 3, 2018)

Pressman, S. (2015). Defining and measuring the middle class. (Working Paper 007). [Online] Available:

https://www.aier.org/sites/default/files/Files/Documents/Standard/WP007-Middle\%20Class.p df (November 15, 2018)

Roach, B. (2010). Taxes in the United States: History, fairness, and current political issues. Global Development and Environment Institute. [Online] Available:

http://www.ase.tufts.edu/gdae/education_materials/modules/Taxes_in_the_United_States.pdf (July 17, 2018) 


\section{Macrothink}

Business and Economic Research

ISSN 2162-4860

2019, Vol. 9, No. 1

Rupeika-Apoga, R. (2014). Financing in SMEs: Case of the Baltic States. Procedia-Social and Behavioral Sciences, 150, 116-125. https://doi.org/10.1016/j.sbspro.2014.09.013

Simron, D., Ganser, T., McLiesh, C., Ramalho, R., \& Schleifer, A. (2010). The effect of corporate taxes on investment and entrepreneurship. American Economic Journal: Macroeconomics, 2(3), 31-64. https://doi.org/10.1257/mac.2.3.31

Sutor, D. (2018, Jan 18). Trump touts tax cuts in Western Pa. appearance. Cumberland Times News. [Online] Available:

http://www.times-news.com/news/trump-touts-tax-cuts-in-western-pa-appearance/article_dae 4aaad-acfb-5caa-aa7c-ba15920079d0.html (June 24, 2018)

Thoma, M. (2010, November 30). Did the Bush tax cuts lead to economic growth?. CBS News. [Online] Available:

https://www.cbsnews.com/news/did-the-bush-tax-cuts-lead-to-economic-growth/ (February $26,2018)$

Torun, H., \& Cicekci, C. (2007). Innovation: Is the engine for the economic growth. EGE University. The Faculty of Economics and Administrative Sciences Economics IV, 1-54. [Online] Available:

http://citeseerx.ist.psu.edu/viewdoc/download?doi=10.1.1.452.4897\&rep=rep1\&type=pdf (July 16, 2018)

Ungar, R. (2012, July 17). The truth about the Bush tax cuts and job growth. Forbes. [Online] Available:

https://www.forbes.com/sites/rickungar/2012/07/17/the-truth-about-the-bush-tax-cuts-and-job -growth/\#55569f074636 (March 31, 2018)

\section{Copyright Disclaimer}

Copyright for this article is retained by the author(s), with first publication rights granted to the journal.

This is an open-access article distributed under the terms and conditions of the Creative Commons Attribution license (http://creativecommons.org/licenses/by/3.0/). 